\title{
Conditions of Minimum Wage IndeXation in Czech and SlovaK LEGISLATION IN THE CONTEXT OF BUSINESS ECONOMICS
}

\author{
Martin Pernica ${ }^{1}$
}

\begin{abstract}
The aim of the article is to assess - on the basis of a comparison of Czech and Slovak legislation relating to the conditions of the minimum wage indexation - whether it would be appropriate to use certain aspects of Slovak legislation in the Czech legislation and vice versa. When elaborating the article, some logical methods were used. In order to collect data, important employers were addressed in the South-Moravian Region. A carrying method used during the work was a comparison. Analyses were processed using the data of the Czech Statistical Office, the European Statistical Office and the Ministry of Labour and Social Affairs of the Czech Republic. To evaluate the research, the percentage representation of positive and negative responses and Pearson's Chi-square test were used. The paper presents the results of research whose aim was to get the views of entrepreneurs regarding the minimum wage level and conditions of its indexation. Employers supported the idea of maintaining the institution of the minimum wage. A predominant portion of companies would welcome it if the minimum wage were derived on the basis of an average wage, and the vast majority of companies would welcome the annual indexation of the minimum wage by inflation.
\end{abstract}

\section{Keywords}

Kaitz Index, Minimum Wage, Tripartite, Law on a Minimum Wage

\section{Introduction}

The minimum wage is the oldest type of guaranteed minimum income variable. It was established in 1894 in New Zealand. A decisive factor for the introduction of a minimum wage was the difficult social situation of wage workers, because employers used strong competition in the labour market in order to minimize their wage claims (Castles, 1996). In the early 20th century, the minimum wage spread to Europe and to the United States of America. In the United States, two models were created over time for determining the

\footnotetext{
${ }^{1}$ Institute of Finance, Faculty of Business and Management, Brno University of Technology, Kolejní 2906/4, 61200 Brno, Czech Republic, E-mail: pernica@fbm.vutbr.cz.
} 
amount of the minimum wage. The first model, which was introduced in Massachusetts, resembled the model from Australia and New Zealand. The minimum wage only applied to women and minors. Special commissions were created, the so-called Minimum Wage Boards, comprising representatives of employers and employed women and minors, who together negotiated the conditions of the indexation of wages (Douglas, 1919).

The second model of the minimum wage was established in Oregon. It was a completely new model that gradually spread to all US states. In Oregon, a law was adopted on the basis of which it was not possible to pay wages that were lower than necessary living expenses. A commission that was formed to determine the level of the minimum wage did not only rely, in its decision-making on the determination of the minimum wage, on the results of negotiations between employees and employers, but also involved government representatives.

The impulse to enact the minimum wage was brought about by the economic crisis of the thirties of the twentieth century. This resulted in a need to improve the working conditions of all employees (Liu, Wu, 1999).

In 1937, the Federal Supreme Court upheld the enactment of the minimum wage. As a result, Federal Labor Standards were adopted in 1938 (Grossman, 1978).

Historically, two possible forms of adjusting the minimum wage were thus created: the minimum wage determined by law or negotiated by a collective agreement.

To further improve the protection of the social rights of workers in the period after World War II, the role of international organizations was crucial, particularly the International Labour Organization, the United Nations and the Council of Europe. Already at the beginning of 1919, the International Labour Organization adopted conventions that regulated night work by women and minors, unemployment and working hours in the industry. Conventions relating to minimum wages were adopted between the years 1928 and 1970 . The most famous is Convention No. 26 on the implementation of methods for the determination of minimum wages (ILO, 2006). Later on, Convention No. 99 was adopted on minimum wage determination in agriculture, dated 1951, and Convention No. 131 on the determination of minimum wages with a special focus on developing countries, dated 1970 (ILO2, 2006). The Czech Republic has so far ratified Conventions No. 26 and No. 99.

In 1975, the Federal Assembly of the Czechoslovak Socialist Republic ratified the International Covenant on Economic, Social and Cultural Rights of the United Nations, dated 1966 (MFA, 1976), which in article 7 contains "the right of every person to remuneration that guarantees - as a minimum - for all workers a decent life for them and their families". In relation to the issues constituting the topic of this paper, article 11 is also important, as it establishes the right of an individual to "an adequate standard of living for him/her and his/her family, and adds to it the commitment to continuously improve living conditions, i.e. the commitment not to conceive the living standard statically, but to dynamically adapt it to the cost of living".

General functions of wages as remuneration for human labour performed include the social function, regulating function, compensating and stimulating function (Galvas, 2004). The amount that a worker receives as a minimum wage should fulfil these functions at a certain minimum level. A worker who receives a minimum wage should be capable of covering 
from these funds the costs associated with living; the minimum wage should provide compensation - to the minimum extent - for his/her efforts and time spent at work, and last but not least should lead him/her to work and not be dependent on welfare benefits. However, how the minimum wage fulfils these functions depends on its amount. Hindls and Hronová rightly point out that, if the minimum wage is high enough and provides to those who work for it at least a somewhat bearable living, it fulfils its role. In the opposite case, it changes into a tool burdening the state with higher amounts of social benefits and becomes a fictitious wage, for which basically no one works anyway (HN, 2004).

The aim of this article is to assess - on the basis of a comparison of Czech and Slovak legislation relating to the conditions of the minimum wage indexation - whether it would be appropriate to use certain aspects of the Slovak legislation in the Czech legislation and vice versa.

\section{Material and methods}

When elaborating the article, some logical methods were used, especially induction and deduction, analysis and synthesis. The main method used in the work was a comparison. Analyses were processed using the data of the Czech Statistical Office, the European Statistical Office and the Ministry of Labour and Social Affairs of the Czech Republic. For the evaluation of the research, the percentage representation of positive and negative responses and Pearson's Chi-square test were used.

\section{Kaitz index}

Most countries derive the level of the minimum wage from the level of the average wage or as a multiple of the living minimum. The Kaitz index is the ratio of the minimum wage to the average wage (Burkhauser, Couch, Wittenburg, 2000). The living minimum is defined by applicable Czech legislation as a socially recognized minimum level of financial income to cover sustenance and other basic personal needs (Collection of Laws, 2006). Applicable levels of living and subsistence minimum are set by Government Regulation No. 409/2011 $\mathrm{Sb}$. (Coll.) on increasing the levels of living and subsistence minimum (Ministry of Labour and Social Affairs, 2011). For an individual who does not have a family, the level of the living minimum is CZK 3,410. In 2015 in the Czech Republic, the minimum wage was CZK 9,200 per month, which corresponded to CZK 55.00 per hour. The amount of the average gross monthly nominal wage was, according to Czech Statistical Office data, CZK 26,278 for the second quarter of 2015 (CZSO, 2015). In 2014, the proportion of the minimum wage to the average wage (the Kaitz index) was $33.1 \%$. Until 2013, the Kaitz index was significantly decreasing, and this is also demonstrated in the following chart showing the development of the levels of living minimum and of average and minimum wages in the Czech Republic in 1991-2014. 
Figure 1: Development of living minimum levels and of average and minimum wages (CZK)

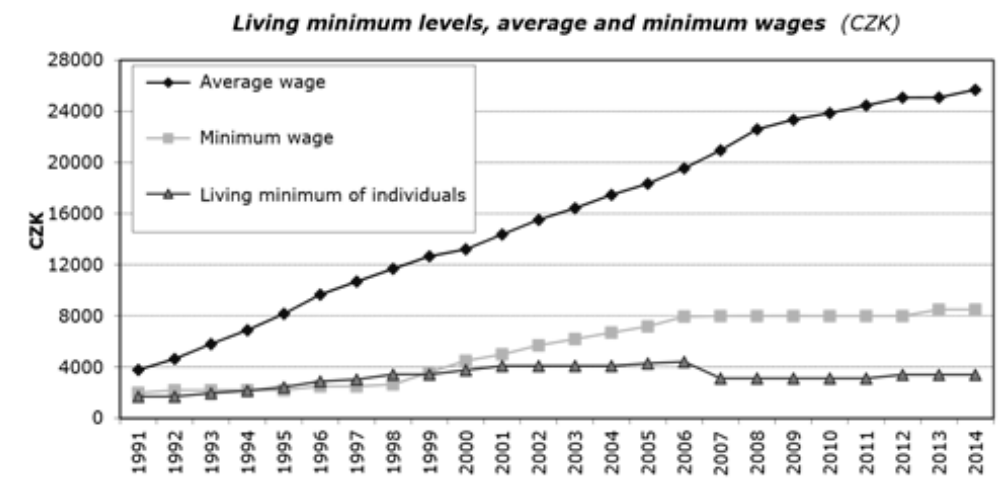

Source: (VUPSV, 2015)

Abroad, the ratio of the minimum wage to the average wage is approximately $40 \%$ (Rycx, Kampelmann, 2012). Should the Kaitz index in the Czech Republic also reach $40 \%$, the minimum wage level would have to be CZK 10,515 per month. Minister of Labour and Social Affairs Michaela Marksová-Tominová set a goal to significantly increase, by 2018, the level of the minimum wage in the Czech Republic, in accordance with the estimated development of the average monthly gross wage, to CZK 11,200 (Marksová-Tominová, 2014).

A further increase of the minimum wage is planned for 2016. The Bohemian-Moravian Confederation of Trade Unions called for a minimum wage increase by CZK 1,000 to CZK 10,200 per month (Středula, 2015). This requirement, however, was rejected by representatives of employers, who were willing to accept a minimum wage increase only by CZK 500 (Kučera, 2015). At the end of August 2015, the government agreed on a compromise - raising the minimum wage by CZK 700 to CZK 9,900 (Czech News Agency, 2015).

This brings about a question: Under what conditions should the minimum wage be subject to indexation? In order to obtain the answer, I will make a comparison of the Czech and Slovak legislation relating to the conditions of minimum wage indexation. 


\section{Comparison of Czech and Slovak legislation relating to the conditions of minimum wage indexation}

\section{The minimum wage in the Czech Republic and conditions of its indexation}

In most OECD countries, the minimum wage is enacted (Martin, Immervoll, 2007). The Czech Republic is no exception. The Labour Code characterizes the minimum wage in paragraph 1 as follows: "The minimum wage is the lowest allowable amount of remuneration for work in a basic employment relationship under Section 3.” The minimum wage applies to employment as well as to agreements on work performed outside employment; its amount is the same all over the country and is not generically delimitated. The amount of the basic rate of the minimum wage and of other rates of the minimum wage graded according to the degree of influences restricting the work opportunities of an employee and conditions for providing the minimum wage is stipulated by government regulations (Government of the Czech Republic, 2006). According to the law, this should be done: "Usually with effect from the beginning of a calendar year, taking into account the development of wages and consumer prices" (Collection of Laws - Labour Code, 2006). The government is empowered by the Labour Code to issue regulations, and it depends on how it assesses the situation whether it is necessary to adjust the minimum wage or not. The above is easy to see from all the above data - especially from the comparison of the development of the minimum wage in the Czech Republic in 1991-2014 to the growth of consumer prices (cost of living) of households in the same period (1991-2014) (CZSO, 2014), and from the comparison of the development of the living minimum, and of the average and minimum wage (1991-2014).

\section{The minimum wage level in the Czech Republic}

Act No. 262/2006 Sb. (Coll.), the Labour Code, paragraph 2 of Section 111, states that the basic rate of the minimum wage is at least CZK 7,955 per month, or CZK 48.10 per hour; other rates of the minimum wage must not be less than $50 \%$ of the basic rate of the minimum wage. (The above rate of the minimum wage is applicable for recipients of a disability pension.) Provisions of the Act are further clarified by the many times amended Regulation No. 567/2006 Sb. (Coll.) on the minimum wage, on the lowest levels of the guaranteed wage, on the definition of a difficult working environment and on the amount of an extra payment for work in a difficult working environment; the Regulation is currently valid and effective as amended by the Government Regulation No. 204/2014 Sb. (Coll.) with effect from 1 January, 2015. The minimum wage is determined by the Government of the Czech Republic in the Regulation in two amounts - as a monthly minimum wage (the amount in Czech crowns per month) and as an hourly minimum wage (the amount in Czech crowns per hour worked) (Government of the Czech Republic, 2006).

Act No. 262/2006 Sb. (Coll.) in Section 79 provides the length of the working time as 40 hours per week. For employees performing work in difficult conditions, the working week is shorter. 


\section{The minimum wage in Slovakia and conditions of its indexation}

In accordance with Section 2 of Act No. 663/2007 Z. z. (Coll.), Act on the minimum wage, the minimum wage level is set for the "respective calendar year" by the Government of the Slovak Republic on the basis of government regulation. Furthermore, according to paragraph 4 , the minimum wage level corresponds to a forty-hour working week.

Slovak legislation provides for two possible methods for determining the minimum wage level. The first is an agreement of social partners - representatives of employees and employers, and the second is the proposal of the Ministry of Labour, Social Affairs and Family of the Slovak Republic.

According to Section 6 of Act No. 663/2007 Z. z. (Coll.), the adjustment of the minimum wage level is carried out with regard to the development of the economic and social situation in Slovakia for a period of two calendar years preceding the year in which it is proposed to establish the minimum wage level. The legislator's preference is agreement between social partners.

When deciding on the indexation of the minimum wage according to paragraph $1-$ paragraph 4 of Section 7 of Act No. 663/2007 Z. z. (Coll.), social partners must take into account the development of consumer prices, employment, average monthly wages and living minimum. If the social partners do not reach an agreement on the minimum wage indexation, the Ministry of Labour, Social Affairs and Family, in accordance with paragraph 5 of Section 7 of Act No. 663/2007 Z. z. (Coll.), submits a draft government regulation at the meeting of the Economic and Social Council of the Slovak Republic, by which the minimum wage is set according to Section 8 . The government subsequently discusses this proposal. In accordance with paragraph 2, Section 8 of Act No. 663/2007 Z. z. (Coll.), the level of the minimum wage for the subsequent calendar year is determined "...at least at the rate of the product of the applicable monthly minimum wage and the index of the annual growth of the average monthly nominal wage of an employee in the economy of the Slovak Republic, published by the Statistical Office of the Slovak Republic for the calendar year preceding the calendar year in which the proposal to adjust the level of the minimum wage is submitted". The Government must decide on the minimum wage level according to the above Act "no later than on the 20 October, taking into account views of the social partners, the development of criteria for the adjustment of the minimum wage level according to Section 6, the development of the ratio of the net minimum wage from the net average wage at least for the preceding two calendar years and subject to the development of labour productivity" (Collection of Laws of the SR, 2007).

\section{The minimum wage level in Slovakia}

The minimum wage is set by the Government of the Slovak Republic in two amounts in the form of a regulation: as a monthly minimum wage (the amount in euro per month), and as an hourly minimum wage (the amount in euro per hour worked). The monthly minimum wage only applies to employees who are remunerated in the form of a monthly salary. The level of the minimum wage, valid from 1 January, 2015, is set by Government Regulation No. 297/2014 Z. z. (Coll.), by which the minimum wage level is set at $€ 380.00$ for 2015 . 
For employees who are paid an hourly wage, an hourly minimum wage serves as a basis. This is also used in cases where an employee has an employment contract concluded according to Section 49, No. 311/2001 Z. z. (Coll.) or did not work the full working time of a monthly time fund (Collection of Laws of the SR-Labour Code, 2001).

According to Section 2 of Act No. 663/2007 Z. z. (Coll.), the amount of the hourly minimum wage is determined as $1 / 174$ of the amount of the monthly minimum wage. For a forty-hour week work fund, the level of an hourly minimum wage is determined by calculating $1 / 174 \times € 380.00$, which - after rounding to three decimal points - corresponds to $€ 2,184$. (Collection of Laws of the SR, 2007)

\section{Comparison of the minimum wage indexation according to Czech and Slovak legislation}

Slovak Act No. 663/2007 Z. z. (Coll.) in agreement with Czech Act No. 262/2006 Sb. (Coll.), the Labour Code, provides that the government sets the minimum wage level by way of a regulation. The Slovak legislation, however, unlike the Czech legislation, imposes an obligation on the government to set a minimum wage for each calendar year according to paragraph 2 of Section 2, or according to paragraph 2 of Section 9. The government regulation must, according to the Slovak legislation, be published in the Collection of Laws no later than on 1 November of the calendar year preceding the calendar year for which the level of the minimum wage is being set.

The Czech legislation does not impose an obligation on the government to set the minimum wage level in advance by way of a regulation for each year separately, and - at the same time - there is no legal deadline within which a review of conditions influencing the minimum wage level should take place. The Czech Labour Code merely states that it is carried out "usually with effect from the beginning of a calendar year, taking into account the developments in wages and consumer prices". When deciding on the minimum wage level, the Slovak government must - according to the law - take into account several criteria that influence employment and the social situation of the population.

In addition to the criteria of wage and consumer prices development, as it is in the Czech legislation, the Slovak legislation provides further criteria - the development of average monthly wages in the economy and the living minimum as further criteria that need to be taken into account in assessing the change in the level of the minimum wage for the subsequent year. The above applies if the negotiations about the minimum wage level take place between social partners or on the ground plan of the Economic Council of the Slovak Republic in accordance with paragraph 1 - paragraph 4 of Section 7 of Act No. 663/2007 Z. z. (Coll.).

In the event that the indexation is decided by the Government of the Slovak Republic on the basis of the proposal of the Ministry of Labour, Social Affairs and Family according to paragraph 5 of Section 7 and Section 8 of Act No. 663/2007 Z. z. (Coll.), other criteria also come under consideration: the ratio of the net minimum wage and the net average wage in the preceding two years, and the development of work productivity. 


\section{Agreement of social partners as a basis for the minimum wage level change}

In Slovakia, like in the Czech Republic, the agreement of social partners is important for determining the minimum wage level. In the case of the Czech Republic, this is represented by tripartite negotiations, consisting of representatives of employers and employees with the participation of the state - the government - as a representative of common interest. However, the principal difference lies in the fact that in Slovakia these negotiating proceedings regarding the minimum wage are specifically regulated by Act No. 663/2007 Z. z. (Coll.), including deadlines, and the Slovak executive power stands more in the background at the meeting of representatives of employers and employees. The legislator prefers agreement between those parties without the executive power having to directly enter these negotiations. Only in the event that the parties are unable to agree, will each of them submit its own proposal to the Ministry of Labour, Social Affairs and Family, and the Ministry further presents it at the meeting of the Economic and Social Council of the Slovak Republic (the equivalent of the Czech tripartite). Here, there is a last chance to make the social partners - assisted by representatives of executive power - agree on the change of the minimum wage level for the following period. In the event that it becomes clear that agreement is not possible, again according to Act No. 663/2007 Z. z. (Coll.), the Ministry of Labour, Social Affairs and Family itself intervenes and prepares a draft government regulation for the meeting.

In the Czech legislation, such sophisticated legislation of the manner of negotiating the changes to the minimum wage level is completely absent.

\section{Evaluation of the comparison of Czech and Slovak legislation regarding the conditions of minimum wage indexation}

In assessing the ability of the minimum wage to perform a social, regulatory, compensating and stimulating function, a major role is played by a single parameter: its amount. In my opinion, it would be appropriate to include certain aspects of Slovak legislation concerning the conditions for the indexation of the minimum wage in Czech Act No. 262/2006 Sb. (Coll.), the Labour Code. The basis for adjusting the minimum wage level should be the consensus reached by representatives of employers (employers' associations) with representatives of employees (trade unions) - bipartite. Only in the event that employers and employees are unable to agree on the minimum wage level for the subsequent year should government representatives enter the negotiations - the tripartite. If even in this case agreement is not possible, each of the parties would submit its opinion, which would become a basis for the decision of the government on the minimum wage level for the period of one calendar year. My opinion is, however, that details of the negotiating procedure should be regulated by law. The Government of the Czech Republic should have a legal obligation to update the minimum wage level during the year with effect always as of 1 January of the subsequent year and always for the entire calendar year. When deciding on the adjustment of the minimum wage level, the government should be legally obliged to consider at least the development of average monthly wages, consumer prices and the living minimum. The law should impose on the government the requirement to index the minimum wage level at least according to the growth of consumer prices. 


\section{Research}

The purpose of the research was to find out the opinions of micro-, small-, medium- and large-sized companies on the existence of the minimum wage institution, its level, the relationship of the minimum wage and the average gross wage (the Kaitz index), and the method of indexation of the minimum wage. Some of the results were presented at an international forum: Ibima Proceedings of the 25th International Business Information Management Association Conference in spring 2015 in Amsterdam (Pernica, 2015). The results will now be summarized and supplemented with hitherto unpresented results concerning the opinions of the company on the Kaitz index of the method of indexation of the minimum wage.

The basis of the research was a questionnaire survey. In the pilot phase, four companies were selected with the goal of assessing content and formal aspects of the questionnaire. On this basis, the questionnaire was modified and re-submitted to respondents for inspection. The main part of the questionnaire survey then began.

\section{Addressing respondents}

In order to collect data, important employers were addressed in the South-Moravian Region. Companies were addressed personally and via e-mail. Companies providing services were mainly addressed. Included in those industries with the highest concentration of worst paid workers in the Czech Republic are accommodation and catering, administrative and support service, real estate activities, entertainment and recreation and retail trade and repair of vehicles. To determine the size of the company, the Recommendation of the Commission of the European Communities was used (The Commission of the European Communities, 2003). In total, 300 companies were addressed in such a way that companies of different sizes operating in diverse sectors according to the statistical classification of economic activities were evenly represented. The questionnaire was predominantly carried out in person. A total of 183 companies participated in the research. Questions were answered by company owners, executive directors and accountants.

\section{Research questions}

The questionnaire was divided into two parts. The first part was concerned with the characteristics of the company (company size, the focus of economic activities, the rate of using the institution of the minimum wage in the company; the second part was in general concerned with the institution of the minimum wage and opinions on its existence, the amount of the minimum wage level, the influence of the minimum wage on the costs of the company, competitiveness, employment, etc.). Given the scope of the research data obtained, the most interesting results corresponding to the intent of this article will be presented in more depth.

Below is an overview of selected questions and the options that were offered. 
Table 1: Overview of selected questions and answers of the questionnaire survey

\begin{tabular}{|c|c|c|c|c|}
\hline \multicolumn{5}{|c|}{ Companies } \\
\hline & $\begin{array}{l}\text { Number of } \\
\text { micro-sized } \\
\text { companies }\end{array}$ & $\begin{array}{l}\text { Number of } \\
\text { small-sized } \\
\text { companies }\end{array}$ & $\begin{array}{l}\text { Number of } \\
\text { medium- and } \\
\text { large-sized } \\
\text { companies }\end{array}$ & \begin{tabular}{|l|} 
Total \\
number
\end{tabular} \\
\hline $\begin{array}{l}\text { Distribution of companies that } \\
\text { participated in the questionnaire } \\
\text { survey according to their size }\end{array}$ & 73 & 56 & 54 & 183 \\
\hline \multicolumn{5}{|l|}{$\begin{array}{l}\text { 1. Indicate the percentage of your } \\
\text { employees in the company who are } \\
\text { remunerated by a minimum wage }\end{array}$} \\
\hline $\begin{array}{l}\text { a) } 0 \% \text { of employees remunerated } \\
\text { by a minimum wage in the total } \\
\text { number of employees }\end{array}$ & 53 & 40 & 45 & 138 \\
\hline $\begin{array}{l}\text { b) } 1-3 \% \text { of employees remunerated } \\
\text { by a minimum wage in the total } \\
\text { number of employees }\end{array}$ & 0 & 2 & 4 & 6 \\
\hline $\begin{array}{l}\text { c) } 4 \% \text { and more of employees } \\
\text { remunerated by a minimum wage } \\
\text { in the total number of employees }\end{array}$ & 20 & 14 & 5 & 39 \\
\hline \multicolumn{5}{|l|}{$\begin{array}{l}\text { 2. Indicate whether in your opinion the } \\
\text { institution of the minimum wage } \\
\text { should exist. }\end{array}$} \\
\hline a) yes & 73 & 56 & 51 & 180 \\
\hline b) no & 0 & 0 & 3 & 3 \\
\hline \multicolumn{5}{|l|}{$\begin{array}{l}\text { 3. Provide your opinion on the } \\
\text { optimum level of the minimum } \\
\text { wage. The minimum wage per } \\
\text { month should be: }\end{array}$} \\
\hline a) up to $\mathrm{CZK} 10,000$ & 52 & 29 & 32 & 113 \\
\hline b) CZK 10,001-12,000 & 11 & 14 & 18 & 43 \\
\hline c) CZK 12,001 and more & 10 & 13 & 4 & 27 \\
\hline \multicolumn{5}{|l|}{$\begin{array}{l}\text { 4. Specify on what basis the } \\
\text { minimum wage amount } \\
\text { should be set. }\end{array}$} \\
\hline $\begin{array}{l}\text { a) The minimum wage level should } \\
\text { be determined on the basis of an } \\
\text { average gross wage in the CR. }\end{array}$ & 27 & 23 & 28 & 78 \\
\hline $\begin{array}{l}\text { b) The minimum wage level should } \\
\text { be determined on the basis of an } \\
\text { average gross wage in all EU } \\
\text { member states. }\end{array}$ & 13 & 14 & 7 & 34 \\
\hline
\end{tabular}




\begin{tabular}{|c|c|c|c|c|}
\hline \multicolumn{5}{|c|}{ Companies } \\
\hline & $\begin{array}{l}\text { Number of } \\
\text { micro-sized } \\
\text { companies }\end{array}$ & $\begin{array}{l}\text { Number of } \\
\text { small-sized } \\
\text { companies }\end{array}$ & $\begin{array}{l}\text { Number of } \\
\text { medium- and } \\
\text { large-sized } \\
\text { companies }\end{array}$ & $\begin{array}{l}\text { Total } \\
\text { number }\end{array}$ \\
\hline $\begin{array}{l}\text { c) The minimum wage level should } \\
\text { be determined on the basis of } \\
\text { living minimum. }\end{array}$ & 26 & 16 & 10 & 52 \\
\hline $\begin{array}{l}\text { d) The minimum wage level should } \\
\text { be determined on the basis of } \\
\text { subsistence minimum. }\end{array}$ & 6 & 0 & 1 & 7 \\
\hline $\begin{array}{l}\text { e) The minimum wage level should } \\
\text { be determined on the basis of } \\
\text { a wage median. }\end{array}$ & 1 & 3 & 8 & 12 \\
\hline \multicolumn{5}{|l|}{$\begin{array}{l}\text { 5. State how the minimum wage } \\
\text { should be indexed. }\end{array}$} \\
\hline $\begin{array}{l}\text { a) The minimum wage should be } \\
\text { indexed each year for inflation. }\end{array}$ & 60 & 49 & 42 & 151 \\
\hline $\begin{array}{l}\text { b) The minimum wage should be } \\
\text { indexed on the basis of the } \\
\text { indexation of the average gross } \\
\text { wage. }\end{array}$ & 9 & 4 & 7 & 20 \\
\hline $\begin{array}{l}\text { c) The minimum wage should be } \\
\text { indexed on the basis of the } \\
\text { indexation of living minimum. }\end{array}$ & 3 & 2 & 2 & 7 \\
\hline $\begin{array}{l}\text { d) The minimum wage should be } \\
\text { indexed on the basis of the } \\
\text { indexation of subsistence } \\
\text { minimum. }\end{array}$ & 0 & 0 & 0 & 0 \\
\hline $\begin{array}{l}\text { e) The minimum wage should be } \\
\text { indexed on the basis of the } \\
\text { indexation of the wage median. }\end{array}$ & 1 & 1 & 3 & 5 \\
\hline
\end{tabular}

Source: (Author's own processing)

Note: The results for medium-and large-sized companies were put together to make the number of elements (companies) in individual groups assessed about the same.

\section{Results and discussion}

Approximately one quarter of the total number of companies that participated in the research remunerates their employees with the minimum wage.

Employers clearly spoke in favour of maintaining the institution of the minimum wage (98\% positive answers). It is interesting that about $40 \%$ of employers imagine a significantly higher amount for the minimum wage than its current amount. At the same time, however, approximately one half of the employers surveyed believe that this institution makes it more difficult to employ workers with a low level of qualification. Approximately $40 \%$ of companies reported that the minimum wage increases the costs of the company so 
much that its existence or the indexation of the minimum wage has a partial or high impact on dismissals of employees. Again, about $40 \%$ of respondents believe that the minimum wage has a negative effect on business competitiveness.

In addition to identifying basic indicators, such as the percentage representation of individual positive and negative answers, a Pearson's Chi-square test was conducted; this makes it possible to verify whether a random variable has a certain predetermined probability distribution. For details on the test, see Greenwood, Nikulin, 1996. Test statistics $\chi^{2}$ were gradually calculated according to the equation

$$
\chi^{2}=\sum_{i=1}^{n} \frac{\left(p_{i}-o_{i}\right)^{2}}{o_{i}}
$$

Where $p_{i}=$ the observed rate of the $i$-th category;

$o_{i}=$ the expected rate of the $i$-th category.

In the case of the first question "Indicate the percentage of your employees in the company who are remunerated by a minimum wage", it was useful to find out if the company uses the institution of the minimum wage in rewarding their staff or not, and if so, what the share is of workers remunerated in this way. In order to assess the question with the help of the Pearson's Chi-square test, the responses were subsequently redistributed only to two alternatives: companies that use the minimum wage institution, and companies that do not use it. After the substitution into the formula, the test criterion is 2.619 , while the critical value for a $10 \%$ significance level is 4.605 . At the $10 \%$ significance level, we therefore do not reject the null hypothesis $(\mathrm{H} 0)$ on the independence of the individual characters.

In the case of the second question "Indicate whether in your opinion the institution of the minimum wage should exist", it was useful to find out if companies have a positive attitude towards the existence of the institution of the minimum wage in the Czech Republic provided by the legislation. The results show at first sight that there is no relationship between the size of the company and the opinion on the existence of the minimum wage institution. Given the great number of null elements, it was not possible to use Pearson's Chi-square test.

The purpose of the third question was to find out opinions about the optimum level of the minimum wage. The survey was conducted at a time when the amount of the minimum wage was CZK 8,500 per month at a full forty-hour work week. According to the results of the Pearson's Chi-square test, it is possible to say that, at the significance level of $10 \%$, we reject the null hypothesis ( $\mathrm{HO})$ on the independence of individual characters, and adopt hypothesis $\mathrm{H} 1$, which tells us that a certain dependence exists. In answering this question, the effect of company size was clearly reflected in relation to its attitude to the level of the minimum wage it considers as optimal.

The fourth question investigated the opinion of the companies on the ways of deriving the basis of the minimum wage. Several completely different alternatives of the answers were offered. In this case, it made no sense to conduct a Pearson's Chi-square test. Answers to this question are different, but the prevailing view among the companies was that the minimum wage should be derived on the basis of an average wage (42.62\%). 
The fifth question served to find out how the minimum wage should be indexed. In this case, several very different alternative answers were again offered. It made no sense to carry out a Pearson's Chi-square test in this case. The percentage of responses in favour of the indexation of the minimum wage according to the inflation level (the increased cost of living) was $82.51 \%$, which is a clear result.

The survey results can be summarized as follows: According to the opinions of companies, the minimum wage institution is needed. In order for the existence of the minimum wage to be meaningful, it needs to achieve a certain level. In this regard, the attitude of the author of the article to the functioning of the minimum wage, as well as the views of professors Hindls and Hronová, is confirmed. At the time of the survey, the minimum wage was CZK 8,500 per month, and the majority of company representatives supported the idea of the amount of approximately CZK 10,000 per month. From 1 January, 2016, the government approved the indexation of the minimum wage level to CZK 9,900. A predominant portion of companies would welcome if the minimum wage was derived on the basis of the average wage, and the vast majority of companies would welcome annual indexation of the minimum wage by inflation.

\section{Conclusion}

In the Czech Republic, the minimum wage institution is regulated by Act No. 262/2006 $\mathrm{Sb}$. (Coll.), of the Labour Code. Only one section of this Act is directly dedicated to the minimum wage. In Section 111 of Act No. 262/2006 Sb. (Coll.), of the Labour Code, the following is provided in particular: a very brief characteristic of the minimum wage; the manner of determining the level of the minimum wage basic rate and other rates of the minimum wage graded according to the degree of influences restricting job opportunities of employees by the government by a regulation (i.e. by legislation of lower legal force); the basic rate of the minimum wage; and legal obligation of employers to provide an extra payment to employees if their wages, salaries or remunerations from the agreement do not reach the minimum wage. The legal regulation of indexation allows the government to index the minimum wage, usually with effect from the beginning of the calendar year, taking into account the development of wages and consumer prices. Other provisions of the Act are also connected with the minimum wage institution, but they do not regulate the method of determination and conditions of indexation of the minimum wage. The Act does not characterize the purpose and meaning of the minimum wage, especially for the labour market and social position of the employees. It does not state what they should be fulfilling. The above-mentioned also cannot be found in judgements of the Constitutional Court of the Czech Republic. Very modest and "appropriately diversified" legislation concerning the minimum wage does not offer enough reasons for the formation of circumstances that would be a reason for these issues to be dealt with by the Constitutional Court and assess their significance and the way of their meeting in relation to Article 28 of Resolution No. 2/1993 Sb. (Coll.) on the declaration of the Charter of Fundamental Rights and Freedoms as part of the constitutional order of the Czech Republic, as amended by Constitutional Act No. 162/1998 Sb. (Collection of Laws of the CR, 1993), and subsequently 
in relation to Article 23 of the Universal Declaration of Human Rights of 1948, on the basis of which the Charter of Fundamental Rights and Freedoms was created (United Nations, 2005). Both these articles point to satisfactory working conditions, which mean the conditions under which a person is employed, including wages, or in which a person works (Tomeš, 2011).

Legislators give space to any government that is in power to answer the above questions - what the meaning and purpose of the minimum wage is, what role it should fulfil, etc. - in accordance with its beliefs and opinions. Indexation of the minimum wage is purely a political decision. Decision-making on adjustments of the minimum wage level reflects the coalition attitude of the parties regarding the very institution of the minimum wage and the economic policy promoted by the government.

\section{Acknowledgement}

The paper represents an output of the specific research project "Selected Problems of Enterprise Financial Management in International Environment" of the Internal Grant Agency of the Technical University of Brno, registration number FP-S-15-2877.

\section{References}

Burkhauser, R. V., Couch, K. A., \& Wittenburg, D. C. (2000). A reassessment of the new economics of the minimum wage literature with monthly data from the Current Population Survey. Journal of Labor Economics, 18(4), 653-680.

Castles, F. G. (1996). Needs-based strategies of social protection in Australia and New Zealand. Welfare states in transition: National adaptations in global economies, 88-115. CZSO. (2014). Český statistický úrad. Česká republika od roku 1989 v číslech. Retrieved from https://www.czso.cz/csu/czso/ceska-republika-v-cislech-od-roku-1989-wau52m1y38.

CZSO. (2015). Český statistický úřad. Průměrné mzdy 2. čtvrtletí 2015. Retrieved from https://www.czso.cz/csu/czso/cri/prumerne-mzdy-2-ctvrtleti-2015.

ČTK - Česká tisková kancelár. (2015). Minimální mzda dál poroste. Podle Sobotky dosáhne 40 procent prüměrné. Retrieved from http://ekonomika.idnes.cz/sobotka-chce-dalzvysovat-minimalni-mzdu-fp6-/ekonomika.aspx?c=A150907_134357_ekonomika_fih.

Douglas, D. W. (1919). American Minimum Wage Laws at Work. The American Economic Review, 9(4), 701-738. Retrieved from http://www.jstor.org/stable/1813165.

Galvas, M. (2004). Pracovní právo (2nd Ed.). Brno: Masarykova univerzita, 370-374.

Greenwood, P. E., Nikulin, M. S. (1996). A guide to chi-squared testing (Vol. 280). John Wiley \& Sons. A Guide to Chi-Squared Testing: Greenwood, P. E. and Nikulin, M. S. New York: John Wiley \& Sons, Inc., pp. 280 +XII, ISBN 0-471-55779-X. AMS 1991 Classification: 62-02, 62F03, 62H15.

Grossman, J. (1978). Fair Labor Standards Act of 1938: Maximum Struggle for a Minimum Wage. Retrieved from http://www.dol.gov/dol/aboutdol/history/flsa1938.htm.

HN. (2004). Hospodářskénoviny. Retrieved from http://full.nkp.cz/nkdb/view/mkdoc.asp? $\mathrm{p} 1=\mathrm{HN} 20040818000039$. 
Hindls, R., Hronová S. (2004). Minimální mzda: ano či ne? Hospodářské noviny, 48, 161 (18.8.2004), 8. ISSN 0862-9587.

KES. (2003). Komise Evropských společenství. Doporučení Komise Evropských společenství č. 2003/361/ES ze dne 6. května 2003 o definici malých a středních podniků. Retrieved from www.institutumeni.cz/res/data/002/000298.pdf.

Kučera, P. (2015). Minimální mzda stoupne o 700 korun, navrhuje Marksová vládě. Retrieved from http://zpravy.aktualne.cz/finance/minimalni-mzda-stoupne-o-700-korunnavrhuje-marksova-vlade/r bd2dd07239cf11e58c710025900fea04/.

Liu, E., Wu, J. (1999). Minimum Wage Systems. Research and Library Services Division Legislative Council Secretariat, Hong Kong. Retrieved from http://www.legco.gov.hk/yr9899/english/sec/library/989rp08.pdf.

Marksová-Tominová, M. (2014). Minimální mzda se zvýší o tisíce, plánuje ministryně práce. Retrieved from http://tn.nova.cz/clanek/zpravy/ekonomika/minimalni-mzda-se-zvysi-o-tisice-planuje-ministryne-prace.html.

Martin, J. Immervoll, H. (2007). The minimum Wage: Making it pay. OECD Observer No. 261 May 2007. Retrieved from http://www.oecdobserver.org/news/archivestory.php/ aid/2217/The_minimum_wage:_Making_it_pay.html.

MOP - Mezinárodní organizace práce. (2006). Úmluva č. 26 o zavedení metod určení minimálních mezd. Retrieved from http://webcache.googleusercontent.com/search?q=cache:uCKYvO094dgJ:www.mpsv.cz/files/clanky/1169/026.pdf $+\& c d=1 \&$ hl=cs\&ct=clnk\& $\mathrm{gl}=\mathrm{cz}$.

MOP2 - Mezinárodní organizace práce. (2006). Úmluva č. 131 o určení minimálních mezd se zvláštním žretelem pro rozvojové země. Retrieved from http://webcache.googleusercontent.com/search?q=cache:rkfmSc3uq6wJ:https:/www.vse.cz/polek/download.php\%3Fjnl \%3Daop\%26pdf\%3D291.pdf $+\& \mathrm{~cd}=1 \& \mathrm{hl}=\mathrm{cs} \& \mathrm{ct}=\mathrm{clnk} \& \mathrm{gl}=\mathrm{cz}$.

MPSV. (2011). Nařízení vlády č. 409/2011 Sb., o zvýšení částek životního minima a existenčního minima. Nakladatelství Atlas Consulting spol. s.r.o.

MZV. (1976). Vyhláška ministra zahraničních věcí č. 120/1976 Sb., o Mezinárodním paktu o občanských a politických právech a Mezinárodním paktu o hospodářských, sociálních a kulturních právech. Nakladatelství Atlas Consulting spol. s.r.o.

Organizace spojených národů. (2005). Všeobecná deklarace lidských práv. Retrieved from http://www.osn.cz/dokumenty-osn/soubory/vseobecna-deklarace-lidskych-prav.pdf.

Pernica, M. (2015). The Effect of Current Minimum Wage Changes in the Czech Republic on the Enterprises. In Proceedings of the 25th International Business Information Management Association Conference. Innovation Vision 2020. Amsterdam: IBIMA. p. 2335-2347. ISBN: 978-0-9860419-4-5.

Rycx, F.; Kampelmann, S. (2012). Who earns minimum wages in Europe? Brussels. 9782-87452-271-0. Retrieved from http://webcache.googleusercontent.com/search?q=cache: 6vfNQ0SRgDYJ:https://www.etui.org/content/download/6218/59451/file/12\%2BR\%2B 124\%2BMinimum\%2B wages \%2BWeb\%2Bversion.pdf $+\& \mathrm{~cd}=1 \& \mathrm{hl}=\mathrm{cs} \& \mathrm{ct}=\mathrm{clnk} \& \mathrm{gl}=\mathrm{cz}]$. Středula, J. (2015). Chceme skoncovat s levnou prací v České republice. Retrieved from http://www.cmkos.cz/manifestacni-mitink-16-zari/4016-3/josef-stredula-chceme-skoncovat-s-levnou-praci-v-ceske-republice. 
Tomeš, I. (2011). Obory sociální politiky. Praha: Portál, 2011, 113. ISBN 978-80-7367868-5.

VUPSV. (2015). Výzkumný ústav práce a sociálních věcí. Vývoj částek životního minima, průměrné a minimálnímzdy. Retrieved from http://praha.vupsv.cz/Fulltext/fakta/graf7.pdf. Sbírka zákonů ČR. (1993). Zákon č. 2/1993 Sb., Usnesení o vyhlášení Listiny základních práv a svobod jako součásti ústavního pořádku České republiky ve znění ústavního zákona č. 162/1998 Sb. Nakladatelství Atlas Consulting spol. s.r.o.

Sbírka zákonů ČR. (2006). Zákon č. 110/2006 Sb., o životním a existenčním minimu. Nakladatelství Atlas Consulting spol. s.r.o.

Sbírka zákonů ČR - zákoník práce. (2006). Zákon č. 262/2006 Sb., zákoník práce. Nakladatelství Atlas Consulting spol. s.r.o.

Sbírka zákonů SK. (2007). Zákon č. 663/2007 Z. z. o minimálnej mzde, ve znění pozdějších předpisů. In: ASPI. Wolters Kluwer SK.

Sbírka zákonů SK - zákoník práce. (2001). Zákon č.311/2001 Z. z. zákoník práce, ve znění pozdějších předpisů. In: ASPI. Wolters Kluwer SK.

Vláda ČR. (2006). Nařízení vlády č. 567/2006 Sb., o minimální mzdě, o nejnižších úrovních zaručené mzdy, o vymezení ztiženého pracovního prostředí a o výši příplatku ke mzdě za práci ve ztíženém pracovním prostředí. Nakladatelství Atlas Consulting spol. s.r.o. 